\title{
TV/Series
}

Hors séries 1 | 2016

Lost: (re)garder l'île

\section{The Promise of Lost (About Season 2)}

\section{Guillaume Dulong}

Translator. Brian Stacy

\section{OpenEdition \\ Journals}

Electronic version

URL: http://journals.openedition.org/tvseries/4963

DOI: 10.4000/tvseries.4963

ISSN: 2266-0909

Publisher

GRIC - Groupe de recherche Identités et Cultures

\section{Electronic reference}

Guillaume Dulong, «The Promise of Lost (About Season 2)», TV/Series [Online], Hors séries 1 | 2016, Online since 01 December 2020, connection on 05 December 2020. URL : http://

journals.openedition.org/tvseries/4963 ; DOI : https://doi.org/10.4000/tvseries.4963

This text was automatically generated on 5 December 2020

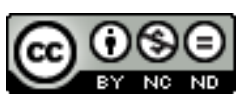

TV/Series est mis à disposition selon les termes de la licence Creative Commons Attribution - Pas d'Utilisation Commerciale - Pas de Modification 4.0 International. 


\title{
The Promise of Lost (About Season 2)
}

\author{
Guillaume Dulong \\ Translation : Brian Stacy
}

I am like a man who, having grounded his ship on many shoals and nearly wrecked it in passing a small island, still has the nerve to put out to sea in the same leaky weather-beaten vessel, and even carries his ambition so far as to think of going around the globe in it. My memory of past errors and perplexities makes me unsure about the future. The wretched condition, the weakness and disorder, of the intellectual faculties that I have to employ in my enquiries increase my anxiety. And the impossibility of amending or correcting these faculties reduces me almost to despair, and makes me resolve to die on the barren rock where I am now rather than to venture into that boundless ocean that goes on to infinity ${ }^{1 !}$

1 After Lost's first season ended with a hit finale that saw its characters blast open the hatch, the stakes involved in writing the sequel were so high that Cuse and Lindelof were quoted saying that Abrams came forward right away to ask them what was beneath the hatch. This mystery forms an underlying theme of this 24-episode run and indeed the entire series - and is solved in the first episode of Season 2. The hatch doesn't contain another hatch, but rather a man, Desmond (Henry Ian Cusick). And he has the key. He enters the "cursed" numbers 4815162342 and presses the Execute button every 108 minutes because "they" - the occult and sprawling Dharma Initiative told him it was necessary for the salvation of the world following an "incident" at the sarcophagus station called "Namaste and good luck". Is it a sinister joke or the truth? Is the character in Lost gullible and conditioned or does he know, or even mean what he's doing? 
2 This first episode, "Man of science, Man of faith", achieved the highest viewership of the entire series, reaching $23,470,000$ viewers in the United States. Nevertheless, after Season 2, Lost would no longer be aired as prime time programming in France. This comes as an even greater surprise given that the terms of the promise Lost makes to viewers. The metadiegetic configurations deployed in these episodes, such as repetition, lay out the rules of the game behind Lost as a communications undertaking, offering a critical reflection on the promise inherent to storytelling and the way in which it ought to be understood. The story's ending is announced within such a framework: in the episode "The End" (S06E17), the question of the button and what happens if it isn't pushed still divides the "same" characters.

3 From that point on, the second season calls for a more attentive, even forward-looking interpretation, as the narrative becomes a cross-media experience. In April 2006, the Lost Experience, a viral marketing operation, reprised, through the variety of these modes of articulating complementary parallel narratives, the theme of the utterance, meaning the secret society and esotericism. The creation of an actual website for the fictitious company Hanso and the publication of the novel Bad Twin, whose author is the character Gary Troup who died on Oceanic flight 815, are part of a process of immersion in the universe conveyed through the Dharma Initiative. These devices allow for a literally religious interpretation - religio being derived from the Latin relegere, "to reread attentively", according to Cicero and Benveniste - to deepen their belief in the world of the promised narrative, by articulating the elements into hypotheses which are systematized into a semblance of knowledge. This knowledge sets them apart from non-experts and laymen so that they can grasp a hidden meaning, anticipate certain events in the narrative and justify certain plot twists. Their understanding, their belief in the unity and singularity of the narrative universe, is made more integral and less shallow thanks to the hypotheses and theories shared by a community of connoisseurs. Consequently, their expectations are greater... and perhaps misplaced - in the sense that we would granting a loan to an insolvent debtor.

The question posited repeatedly by ultra-orthodox Losties on discussion forums is, "Have 'they' predicted the end? Is everything already written? ", making Cuse and Lindelof the masters of the Grand Orient Dharma, provoking the irate frenzy that erupted on May 23, 2010 against said false prophets on the same forums. The reproaches swing back towards Abrams, and to the screenwriting team dubbed Bad Robot, for being teasers rather than narrators, turning the plot into one big MacGuffin enabling them both to break all their promises at the end, while also using pathos and other high-powered effects merely to usher in virtuous love-hate relationship reversals between characters. They are like the Others, like the cynical Grand Inquisitor from the legend of Ivan by the Brothers Karamazov, who sets out to rule mankind through mystery, wonderment, and authority. However, the series doesn't fail, least of all the John Locke character, to warn against a delirium of inevitably disappointing overinterpretation: in Season 2, numbers and other hieroglyphics introduced grow in direct proportion to characters' paranoia and resentment.

On this point, Pacôme Thiellement observes that the Dharma treasure hunt and its cryptic symbolism literally presents us with stations, stages through which we can come up with a fuller, more learned and culturally grounded interpretation of the narrative. This intertextuality deepens our love for the story itself as well as for the literature (novels, plays, myths and biblical writings) to which it refers. For example, 
we find out that the number 108 is the sum of 4, 8, 15, 16, 23 and 42, that it also alludes to the number of beads in the Buddha's rosary, along with the numerical value of Gehenna according to the Kabbalah. The search for insight creates a shared space for exchange among investigators of the series. Nevertheless, merely harvesting data isn't enough; a new unifying factor is needed to explain the conjunction of these seemingly mutually exclusive references: how is it that the same device is designated both as a pathway to enlightenment and a valley of tears?

6 The stations are therefore transit stops, literal waystations. Moreover, through a dialectical shift, the narrative trajectory dooms the stations to be destroyed, prompting a lively audience reaction. In other words, understanding Lost becomes a handicap if the different semantic levels involved are hypostasized by the viewer opposing a superficial literal meaning to an essential figurative meaning. This fact does not mean that such a dividing line is pointless, that whoever ranks and orders the narrative's levels of meaning is necessarily a fundamentalist, but that at the end of the day, such a value system must itself be assessed. Otherwise the reading of the story is static, i.e. esoteric and authoritarian, and the faithful viewer runs the risk of turning into an inquisitor.

With this in mind, we offer to study the manner in which the themes of faith and sacrifice are dealt with in Season 2. This will lead us to question the degree of belief to be ascribed to the audiovisual narrative itself. Our hypothesis is that the narrative promise of Lost calls for a purposeful suspension of disbelief mimicking the operation of the hatch: the narrative repeats its initial promise (to resolve the catastrophe of the crash landing on the Island) if we reiterate our assent, while running the risk of being disappointed caused by its very repetition. The latter heightens expectations of a future outcome while appearing to discredit the story's content through an on-the-spot reference effect.

8 The resetting of a countdown timer in the Swan Station every 108 minutes plays a function deemed to be fairly plausible, given the fantasy and science-fiction genre conventions favored by the season. It is therefore believable that pressing the button will save the world. However, as Locke demands of Jack, it requires us to perform wilful self-sacrifice. It is an allegory of the twofold process of reading/interpreting a television series in response to the twofold writing/rewriting process peculiar to this narrative type. Such stories have to play on both the repetition of familiar situations and on the eruption of events and reversals that are just catastrophic enough to reset the counters from one season (or even one episode) to the next: climax, cliffhanger, anagnorisis... As Umberto Eco shows in his analyses of comic books and soap operas, these narrative techniques mean that serial fiction, despite the postulate of a holistic timeline linking episodes together, tends to unfold in an intransitive present dimension. This present tense is somewhat akin to the synchrony of structural analysis, but also to the routine, even nostalgic symptomatic denial of neurotic behavior and post-traumatic procrastination. Little by little, each episode seems to be neither the consequence nor the cause of any external event, but nevertheless continues to produce reciprocal effects (rather than progression) arising from situations, characters and thoughts. Plot twists in Lost unfold almost as standalone phenomena, flouting any objects, or even reasons, to oppose or rally around. Therefore, at the end of "Man of science, Man of faith", we're mildly surprised to see that the man who was talking to Jack in his flashback is the man living underground. The story's universe consists at 
this point of a coherent disorder, or a flat and mundane multiverse, more than an order harmonizing disparate parts. The sub-promises and sub-plots' sub-recognitions are repeated in each episode with different characters, of course, but according to similar compositional codes. In this context, they acquire a confirming function that is as spectacular as it is predictable. This reassures us in the short term but postpones the original problem and pushes the ultimate deadline ever further down the road. Fiction therefore fuels a distressing avoidance of the long term, that is to say, an increasingly undefined role assigned to adventures in relation to the main initial questions.

There' s something dizzying about such a script that irks those eager to believe in a single, finite plot and regard pathos effects as tacky when used for the sake of postulating a diachronic sense of closure that fulfils the initial promise. Such viewers are partly right: the iterative present tense of the episodes is déjà vu, cliché, and even Lost time in the Proustian sense of the term, the kind that one cannot and does not want to live in the present tense in its full capacity, but that one imagines based on past memories or future plans, whether not they've already been made, combining just those same memories. This is what the show's characters experience on the Island. They do not understand this in any present actuality, but as representation, that is, relative to similar flashbacks or even flashforwards. Likewise for we spectators, the series' usual present constitutes a past performance because we recognize it from our memory of the narrative's opening promise as we await an ending that assigns meaning to it in a meaningful diachronic sequence, but it is a past performance that doesn't declare itself as such. Like denial, this iterative present claims to dismiss the passage of time (the story's beginning and end) while implicitly admitting it. Therefore, by deferring and entertaining the question of passage, it increases the content of a promise and expectation of an end made agonizing and dizzying by the fact that it is objectively unsustainable. Gabriel Bortzmeyer captures this wonderfully in making Lost a metaseries, writing: "Everything was already in Lost, a stagnation and survival-based plot par excellence, where a glimmer of hope makes possible the narrative of its disappointment. Gaining time, pushing back the time limit, that's what the characters and, with them, the series is all about."

10 However, to rant about the dizzying quality of serial writing, as those who hurled online abuse at Cuse and Lindelof, only makes it stronger, for to do so is to deny the angst caused by the ending. Yet the writers relentlessly herald and usher in Lost's conclusion, not just within the narrative, but as a call beyond the narrative. Understanding this appeal through "a modicum of hope" enables us to recover Lost time, and even gain time, in the sense that Tarkovsky, director of the Dostoyevskian or pre-Lostian Stalker (1979) declared that watching a film is not so much a waste of time but a gain because it changes the way we look at the world. Thus, the resetting of the timer also evokes the ritual and homey emotional relationship that the viewer experiences when watching the series, as well as the theoretical relationship between the various episodes, needed to create a self-proclaimed grand and all-encompassing narrative, which is not just an aggregate of miscellaneous theatrics. However, the resetting of the timer causes characters and viewers alike to waver between disbelief and delight, so much so that the paradoxical result is that the station must be sacrificed to save it.

11 It is to this end that the series explicitly refers to the "leap of faith" scheme, the plunge into uncertainty, even absurdity. Some of Lost's characters are clearly destined to 
perish: they take extreme risks, opting for the most improbable solution, if not objectively, then at least subjectively. They undertake acts whose outcomes are theoretically possible, but whose occurrence, is not up to them, hence the evocation of the inescapable opposition of chance and fate when deciding on their choice. At the same time, they are resigned: they are convinced of the improbability not only of the event's realization, but also of the supposed causal relation between the initiated action and the predicted event. Finally, they are led to profess their will to perform the action and having freely made up their mind. This approach calls to mind a radical version of the willing suspension of disbelief on the part of the viewer of fiction; an attitude required, at least tacitly, by the narrator. Radical because the serial narrator, by piling on climaxes and pathos to the point of improbability, seems to violate the generic rules it lays down, demanding a more intense fervor from the viewer.

The risk taken in asserting what the narrator holds would make it possible to oppose ordinary beliefs, on the one hand, which are relatively justified, and faith on the other. The former is self-serving and granted after deliberation, and therefore subject to conditions. The second is disinterested and granted without any rational justification, or even, for the most radical versions, despite rational justification. However, this "leap" into pure possibility is a matter of lived experience, of a present tuned in to an uncertain future. Expressing this in narrative is problematic since the narrative imitates itself and repeats; in theory, it's set in the past: it is assumed that the writers are reciting, in other words the end is already known to them, which precedes, as a matter of course, the beginning for the viewer, an assumption that instils confidence in the promise of the narrative. Thus, the temporal experience that viewers undergo when awaiting future episodes is less an embrace of sheer possibility (even if what is told belongs to the fantasy genre) than a form of induction or even abduction of what the writers most likely have already thought up.

To introduce this "leap" by itself would mean referring directly to the Other, to something beyond the unstoppable narrative, to an intimate relationship between writers and viewers, or even among viewers via the writers. Depicting this "leap" is therefore challenging; it would imply representing the unrepresentable: which can only be done indirectly, by recounting within the narrative the contradiction, misery and vanity of the belief in the final justification of acts, and by way of reflection, the vanity of believing in the narrative. The paradox being that bringing this narrative misery to light through narration is, in Pascal's words, what makes it great. To do this, on the one hand, the series portrays the "leap" as dependent on a past representation of a character via flashbacks. On the other hand, as said previously, with each episode, this past is duplicated by being concealed from itself and by understanding itself in the mode of an iterative, habitual present, similar to a sealed-off moment made of habits that enclose a trauma out of fear that opening up to the future might lead to selfcontradiction. Fervor in the series (and fervor about the series) turns out to be ambiguous: does it trust in reality and in the other beyond our selfishness or obsessive dogmatic denial, or even our despair and resentment?

This ambiguity feeds back into the narrative's theme of sacrifice. It reflects our own relationship to the narrative, since to recount the contradiction, misery and vanity within the narrative and to call for something beyond the narrative (at its end) is to conceive of it as a sacrifice. In this sense, the authors call upon us to question the sacred and the holy, at the boundary between sacrificing the Other for one' s own sake 
(or even sacrificing oneself against the Other), the unrepresentable as violence, and self-sacrifice for the other, the unrepresentable as openness to the Other, via biblical references in general, and chapter 22 of the book of Genesis and the allusions to its Kierkergaardian exegesis Fear and Trembling in particular. Does Lost offer us a model of justification allowing us to distinguish extravagant belief from reasonable belief, or even revelation? To answer this question, we will focus specifically on three episodes written by Cuse and Lindelof in the second season. First, "Man of science, Man of faith" (S02E01) asks who embodies this opposition between the man of science and the man of faith, and therefore said opposition denotes. Secondly, "? "(S02E21) is a good opportunity to examine the resonances of Locke's despair with the kind of writing to which the series refers. Finally, the study of the episode "Live together, Die alone" (S02E23-24) prompts us to consider the ethical and even eschatological dimension of belief in the choice of Desmond's sacrifice.

\title{
Man of science, Man of faith
}

\author{
In the realist, faith is not born from miracles, \\ but miracles from faith. Once the realist comes to \\ believe, then, precisely because of his realism, he \\ must also allow for miracles ${ }^{2}$.
}

Entitled "Man of science, Man of faith", the first episode of Season 2, Locke and Jack appear to have it out over the value of the hatch, a standoff that will be "resolved" between the two characters - in the "Orientation" episode (S02E03), when Locke gets Jack to press the button by arguing how tough it is to make a "leap of faith". For Jack, the hatch can only have a pragmatic and determined function: to shelter the community of survivors, protecting them from the hypothetical threat of the Others. According to Locke, its purpose is less a one-time and local one than that of a makeshift shelter; it is the reason for their presence on the Island. The title of the first episode leads us to think that John and Jack are archetypes, the priest and the scholar - a couple evoking that of Ivan and Alexei in Dostoyevsky's novel The Brothers Karamazov, to which explicit reference is made in the episode "Maternity Leave" (S02E15). Between them, a metaphysical dispute arises: is there a universal finality at work in the series of events and actions of each character capable of bringing them into harmony? In a way this problem has a narratological resonance: is there an intelligence at work ordering the episodes, a providential narrator prescribing a single meaning to the narrative, or is it the product of a learned monkey punching on a typewriter, of a kaleidoscope collating cliché narratives at random?

For Locke, the miracle worker of the first season, there is a mysterious guiding force, a destiny allowing a series of events to be interpreted as signs, trials and paths to salvation. From the moment Locke meets Desmond, he believes in the device and makes a point of pressing the button every 108 minutes after inputting the numbers that made Hugo (Jorge Garcia) both rich and miserable. Still, Locke's motives are not clearcut: already during the first season, in the episode "Deus ex machina" (S01E19), his fatalistic outlook is associated with his father's betrayal and feelings of resentment. However, in the episode "Orientation" (S02E03), we note that the use of the expression "leap of faith" calls to mind a past experience: Helen (Katey Sagal), his companion, uses this phrase to urge Locke to believe in her and put aside revenge against his father. 
17 Jack, the neurosurgeon, takes a cautious line before affirming or repudiating any judgment. He explains the course of events as facts by identifying general principles without venturing to examine the underlying metaphysics. He doesn't believe in the Swan device and has no desire to take over the role of Desmond assigned to him by Dharma, considering his behavior to be conditioned. According to Sander Lee, Jack blames Locke for his bad faith (in the Sartrian existentialism sense), accusing him of shirking his responsibility, of denying his subjective freedom, or forfeiting his faculty of choice. But Jack is also acting out of bad faith in his pretence of choosing according to a self-contained and ego-centered metaphysical freedom stemming from an indifferent world about which only Locke cares, for he then disavows his desire for Others, refusing to acknowledge the role they play in his own decisions. If Jack doesn't believe in the hatch, it is because he recognizes Desmond the person: he's relied on him in the past, in a different and more intimate sense than a heroic belief in saving the world, and he does not care to repeat this experience.

Objectively, the act of "entering the numbers" resulting in "saving the world" may seem implausible. At best one saves a part of the Island and the survivors. Observation of the device - a dated-looking backdrop left over from the 1970s, an outdated computer housed in a dome, a $3 / 6$ aspect ratio film in Super 8 resembling a new-agey corporate video - and the frenzied manner with which Desmond seizes it may indeed suggest conditioning. Desmond convinced himself that he was saving the world by repeating the same sensory-motor sequence over and over again. Having formed a habit, or an easy comfort in carrying it out, Desmond's justification for its continuation is ideological. Rite taking precedence over myth, so to speak.

This idea is made even plainer by the season's opening showing a faceless individual, a ripped body caught up in a mechanical daily routine reacting to its environment with indefatigable purposelessness. However, the eye that kicks off each season is not the episode's first significant moment, but its second: the opening eye is Desmond's motor reaction to an originally unseen sound stimulus, the beep of the timer. In her analysis of the sequence, Sarah Hatchuel points out that the continuous reoccurrence of The Mamas and the Papas - in a manner which is neither over nor completely discrete presents us with a lapsed phasing in contrast to the song's lyrics, an ode to original behavior. This audiovisual opposition between faceless uniformity and claims of outstanding singularity is not so much a logical contradiction as a paradox: the more special Desmond thinks he is, the more he repeats himself, repeats his actions, and so on. It is the delirious logic of the hatch to which this sequence gives us the key, and calls to mind the dark logic of hatred and self-deception that drives the bipolar and paranoid narrator of Dostoyevsky's Notes from Underground.

However, the flashbacks in the episode "Man of science, Man of faith" show us that Jack refuses to believe in the hatch because of an incredible event he experienced. He was disappointed by a promise and above all, disappointed himself. As Lindelof states in the Season 2 bonus DVDs, the man of science/man of faith opposition does not so much refer to Jack and John as two sides of the same Jack. The doctor doubts the Swan device not so much out of rational imperative - he experiences the magnetic attraction of the key to the gun case against the focus of the incident - but because he witnessed a miracle, Sarah's (Julie Bowen) recovery. Nevertheless, this miracle is not the consequence of orthodoxy, of the belief in an objective destiny. It is based on a promise made to Sarah in an ethically borderline situation. This is analogous to Locke's trust in 
Helen since in this episode Jack temporarily drops his rivalry with his father to try to understand the meaning of his advice. It is because he believed in a life-saving miracle that Jack subsequently becomes doubtful about the hatch saving him. His doubt is both a state of greater lucidity and blindness to his role in this earlier miracle. Jack is more lucid in that he has understood that the extraordinary event was not of his making. However, this realism which claims to mourn his omnipotence conceals a blinding state of despair. In effect, the event was not of his making; Jack regrets it and holds onto this regret as revenge. Therefore, he delights in the assurance of his powerlessness, thusly exacting revenge against the others' hope (Christian, Locke, Sawyer), even on the hope given to him by others' hopes (Sarah, Kate), by declaring all miracles to be impossible. Therefore, the static dualism of "man of science and man of faith" does not hold. The series reminds us that the border between knowing and believing is not so watertight, but it is rather a question of corollary attitudes questioning the role of doubt. This is why the character who resolves the crisis, Desmond, is the homonym of a Scottish philosopher self-described as a moderate skeptic, David Hume. Indeed, one can define belief as a propositional attitude that enables us to affirm an opinion as valid for us, therefore conditionally rather than in and of itself, absolutely. Belief hinges on a subjective disposition forming the basis upon which one affirms or denies a proposition. By this act, one supposes the existence or non-existence to us of said proposition's content. By contrast, knowledge, according to the famous Platonic definition of the Theætetus, is a true (objectively, really) and justified belief, backed by its definition. This allows us to envisage the independent existence of a shareable reality made up of entities with a stable and lasting identity.

Belief and knowledge can therefore be considered as two subjective attitudes with regard to the manner of asserting or denying opinions. In pure belief, the validation of judgment depends above all on particular subjective assent: he who asserts or denies the judgment may not know whether it is objectively true or false and may not demonstrate it, i.e. may not previously have shown sufficient objective grounds for such assent. On the other hand, in knowledge, the particular subjective assent to the judgment is mediated by the universal, that is, it follows the demonstration of its truth, and not of its falsehood, as well as sufficient objective conditions: a prior shareable definition of the objects of the judgment and of the properties predicated on them, the non-contradiction with already known judgments and the possibility of bringing it back to an observable factual state. In Cartesian terms, he who knows retains his will to accept or deny a representation by submitting it to his understanding: he therefore doubts, whereas he who believes puts his will before any objective explanation.

This means that there is a certain type of belief, which could be called empirical as it relates to those sensations and imagination that knowledge can sanction or even correct with error. And this, according to a principle of reality, that is to say by limiting our egocentric tendency to see the world commensurate with our particular desire, by recalling the objective and independent existence of a reality outside of ourselves that is the same for everyone or in itself, indifferently. In this light, Jack behaves in a "Cartesian" way during the flashback about him in Season 2's first episode: he tells Sarah about his diagnosis by subjecting himself to a statistical and objective necessity. He announces the probable outcomes of the operation that he'll be performing with the detachment and expertise of a technician. He will be chided by his father, Christian (John Terry), for showing improper restraint, as he is not addressing an object but 
another subject: in this situation, the truth and justification of the statement is not dependent alone on informational accuracy. The announcement must account for the listener's expectation, just as the narrator of a story would do with his or her audience. But Jack first hears this advice as a rhetorical appeal when rebuffing his father, because the expectation that the promise to cure Sarah will raise is quantitatively inordinate, even if qualitatively this is what she wants to hear. He is right: it is rhetoric, but it is paradoxical. On the one hand, it implies an awareness of the eminent improbability of the outcome, or even its impossibility. On the other hand, it only takes into account the expectation of the listener as such, the expectation as a pure opening to the possible of a unique being and not as a prediction of something for some particular interest.

The acute awareness of loss for the sake of the recipient's pure expectation also distinguishes this promise from a normal ethical commitment, from the point of honor, presupposing that nobody is held to impossible deeds. Here it does not depend solely on him that the promise is kept, but on trust in the person to whom the promise is made. This not only puts Jack at risk of not living up to his father's fantasized excellence and intransigence, but of incurring a loss such that it demeans his father's obsession. This implies another type of belief that rational discourse cannot fully redeem. It is based on principles and definitions of absolute objects that one has to accept in order to demonstrate the rest, but whose existence or non-existence cannot be proven without paralogy.

"To believe in his own destruction is impossible. To understand that, humanly, it is his own destruction, and then nevertheless to believe in the possibility, is what is meant by faith." This other type of belief belongs to the order of faith, that is to say, an intimate, categorical and singular conviction that is similar to what Kierkegaard calls "jumping" not only into the unknown, the unexpected, but into the absurd. The absurd is not simply the objective mode of the impossible logic of the "square circle" type. It is on the contrary the pure possible, but one which exceeds the conditions of objective demonstration. It is literally improbable, although necessary to any rational justification. The absurd is therefore a speculative paradox opening up to the ethical attitude of resignation, or even to a metaphysical inquiry ultimately rooted in the intimate experience of finitude, of isolation, of downfall. This experience is what Kierkegaard calls the "affective tonality" of anguish or despair - which could be poetically expressed in Shakespeare's Hamlet's famous "To be or not to be". This disposition is felt as a vision of the absolute, of eternity, through the relativity of appearances and their becoming. Eternity, in its transcendence, its difference from the world of phenomena, is perceived as an eminent possibility of the nothingness of this world. More prosaically, all that unfolds in time becomes, for the anxious, contingent, likely to be only an illusion without rhyme or reason, a veil of Maya, without ontological density.

From an ethical point of view, this pure possibility resolves itself into a necessity, a categorical imperative. The absurd is then understood in the mode of resignation and the "hard reality" which is that of moral or even civil duty (roughly speaking, Kantian rigorism): the individual will has to be reasoned for. It is necessary to give up on explaining certain theoretical problems, just as it is necessary to give up on deriving moral obligations from maxims of particular interest. Autonomy consists in submitting oneself to a pure abstract will, duty, by silencing one's natural feelings and the question of happiness. Thus Agamemnon resigned himself to sacrificing Iphigenia because it was 
necessary for the community. Being autonomous, he put the interest of the Greeks before his own interest, it was his virtue. The All takes precedence over the part; one must obey to obey. But this resignation is despairing, and this condition, that of modern man, is perfectly illustrated in the series by the figure of the hatch man. It is an allusion to the "man from the underground", a petty civil servant from St. Petersburg, a megalomaniacal and powerless narrator, eaten away by envy and hatred of his resignation from Dostoevsky's Notes from Underground.

The "leap of faith" consists in not resigning oneself and wanting the Being by becoming fully aware of its improbability, that is to say, in full awareness of the downfall. According to the problematic exegesis of Genesis 22 produced by the Danish philosopher in Fear and Trembling, only the individual who has resigned himself to the general and who simultaneously and in spite of everything affirms the individual, is fervent, knowing that he then faces anguish by immediately confronting the absolute. The recurrence of the themes and terms "Island" and "Other" shows that the series clearly presents a metaphysics in which the question of the transcendence of the Being is determined by that of the Other. "Where is your brother? "is the biblical question in Genesis 4 that torments Jacob and the origin of the "Thou shalt not kill" that prevents the Man in Black from eliminating the candidates (and which he constantly tries to circumvent); a question at the very foundation of metaphysics, according to Levinas, preceding the anguished ontological question "Why is there something rather than nothing?". Anguish is distress at the death of others. In this framework, Jack's promise shows the change of attitude that the character assumes with others, discovering that it is this relationship that shapes his own identity. It is also with such an approach that Helen obviously refers to Locke, asking him to give up on blaming his father, then Locke to Jack, imploring him to press the button.

In "Man of science, Man of faith", Jack is a man of faith because, for the first time, he cares for others in a way that isn't tied to his self-esteem. The allusions in the second flashback to chapter 18 of the book of Genesis reveal that at this time he is no longer dealing with a particular example of the "patient" that he must mend, but with others in his transcendence: Sarah shows herself in this moment of promise, through her laughter, as patience itself. Indeed, after his interview with Kevin (Anson Mount), Sarah's fiancé, who announces that he will leave her if she is no longer sexually "operational" and therefore able to have children following the operation, the doctor takes the risk of promising the improbable, her recovery, and takes responsibility for her because he understands her expectation. The expectation here has an inseparable moral meaning (Jack sees his responsibility for Sarah's well-being and dignity), and a physical meaning (the expectation or "expecting" here referring to pregnancy). This is why she laughs at the doctor's promise because she herself no longer resigns herself to the resignation to which their first interview had driven her. However, it is in a moment of uncertainty about the outcome of the promise that he meets Desmond, blaming himself for having promised while knowing that the promised thing was almost impossible, as he is convinced of having failed. Through a certain logic of the absurd, of the "why not? "by asking him what would have happened if he had succeeded despite everything, Desmond does not simply seem to remind him that everything is relative, but above all relational. Thus, a promise is not understood solely by the observation of an objective state of affairs, but by the interpretation that one is likely to offer to others, or even that others are likely to offer to us. 

causing us to fall into the order of metaphysics. The advent of what is promised to others and for others presupposes the sacrifice of one's philanthropy by someone promising just as much as an admirable real event. However, this event is marvellous because it is unique and transcendent, it is an advent, an epiphany. In fact, it cannot be repeated without risk, that is to say without the character attributing it to his own capacities and without the relationship to others falling into the relationship. This is what Jack and John understand in the flashbacks devoted to them, in the episodes "The Hunting party" (S02E11) and "Lockdown" (S02E17): they lose the women they love by wanting to repeat and counterfeit the risk-taking that had united them and continue, in all the other flashbacks of the series, to be the agents of their downfall. They seek to repeat this first time because they refuse to be loved back and, citing the alibi of rivalry with their fathers, prefer to revert to entirely one-sided relationships with their loved ones rather than face up to a mutual relationship. In this way, they offer up the lovers for whom they had previously sacrificed themselves and embalm the first "leap" from that promise in order to view it as a mere "incident". And it is around the focal point of this "incident", of the promise as Lost, that a sarcophagus adorned with hieroglyphics is set. The latter is a collection of self-justifying messages about the envious behaviors of the characters, that is to say, all their flashbacks. Through them, the characters claim to dismiss the downfall in a repetitive manner, rather than acknowledging that they themselves have made a downfall of this promise.

In the same way, in terms of the reception and articulation of fiction, by repeating this miracle, curious spectators run the risk of ascribing it to the savvy calculus of an author who may then indulge in becoming this demiurge. In this backward-looking illusion, it seems to us that the unexpected outcome of the lottery was already contained in the drawing and the choice of numbers; we then obviate the lived uncertainty that made it possible, to recall a comparison by Kierkegaard also highlighted in Lost. If the Danish thinker used the word "leap", it is because he couldn't define faith conceptually (being beyond the scope of demonstration), and because he acknowledged that this experience had to be communicated and repeated, hence the autobiographical writing, with its homily and confessional qualities, made up of fictional commentaries, biblical material and personal experiences - which, in the series, questions the narrative's ability to capture these miracles, these intimate encounters, to bring them to life and share them with the public. However, this retelling is ambivalent, because it can turn its characters or its author into miracleworkers, and the spectators into a dogmatic cult. This, again according to the Danish philosopher, is the problem of repetition, a ritual that the series illustrates with the resetting of the timer every 108 minutes in the sarcophagus containing the incident.

31 The narrative thus ironically reminds us that the characters are not the cause of these miracles, although they are tempted to think of themselves as lonely heroes. This can be seen in the sequence of the meeting between Jack and Desmond, which ends with a kind of running pun in this season. The Scotsman, while nursing Jack's ankle, advises him: "You have to lift it up", or "You have to lift it up (your ankle)", but he has such an accent that one can hear, alongside Jack, "You have to lift her up", or "You have to lift her up (Sarah)". This stroke of humor reveals to Jack that his devotion to Sarah is neither a formal pledge clashing with an animal impulse, nor a blind animal impulse adorning itself with the robes of chivalrous values, but a love that must not go 
unheeded. He is not an epic hero, nor is he tragic despite appearances to that effect. He is not a noble soul who sets everything right but with whom everyone treats unfairly (Sawyer, Kate, Sarah and especially her father): this is the pleasing tale that the series tries to put to rest. However, he has to promise Sarah and press the button to repeat the promise and begin to understand the story. This also means that, for the imaginary discourse that forms Lost's narrative, singular faith, general knowledge and particular belief are hardly discernible without viewers' commitment, knowing full well that they will not exhaust the meaning of the narrative, as Pacôme Thiellement points out, for whom the problem of Lost rests on the opposition between confidence and defiance, or even dialectics, the oscillation between these two feelings, of which the opposition between belief and knowledge is the secondary form of justification. Indeed, one of the major themes of the story is the downfall, not only physical downfall, but moral or even metaphysical downfall, resentment, despair as a contemporary evil.

All human actions, of course, will then have to be worked out by those laws, mathematically, like a table of logarithms, and entered in the almanac; or better still, there will appear orthodox publications, something like our encyclopedic dictionaries, in which everything will be so accurately calculated and plotted that there will no longer be any individual deeds or adventures left in the world ${ }^{3}$.

The voluntary suspension of disbelief is particularly criticized in episode 21 entitled "?" in which Locke and Eko (Adewale Akinnuoye-Agbaje) discover a third station offering a reflection on the enunciation and reception of the narrative not only of the first and second seasons but also of all those that will follow because the open crisis will never be totally resolved, except by a cryptic assertion by Hume: "But you saved my life, brother, so that I could save yours. The station is under a bi-plane containing statuettes of the Virgin filled with cocaine, an ironic ambivalence of the object of religious belief, presented both as a sign of mystery (the question mark) and as a drug, the opium of the people, serving only to entertain them in their despair. The Betacam orientation video announces that the members of the Swan station believe they are undertaking a hugely important task and that they're the subjects of a psychological test on submission to authority; the members of the Pearl station will have to observe and record their actions. At this revelation, Locke considers that The Swan is only an illusion, a sham involving sadistic leering and perhaps even vacant chairs, and that the men in the hatch are nothing more than laboratory rats. Distraught, he considers himself a victim of his propensity to imagine the world as conforming to his desires and, instead, reality appears to him as nothingness, a hollow spectacle, a game of opposing effects without rhyme or reason. His rage comes to a head as Eko, the real phony Catholic priest, echoes the enthusiasm that Locke himself used to profess and for almost the same reasons - reasons that his hatred now tells him are foolish. It is as a result of a dream (a justification that Locke admits in the series) that the Nigerien walks to the station and agrees to press the button. He is obviously Locke's double and therefore his rival in terms of fervor and sense of sacred calling. Consequently, Locke, to whom no one 
should say what he cannot do, intends to distinguish himself from this double at all costs, even if it means destroying himself, even if it means destroying everything.

Indeed, Eko infers the importance of the task at hand from impressions of the continuous input of the series of numbers and the orientation video. If the activity is monitored, if it is shown, then its repetition is significant to the viewer, likely to find meaning in it, as opposed to the person pressing the button, who may doubt the relevance of his or her actions. On the other hand, in any case, the statement of the orientation video is such that it teaches us that the object of the psychological test is the participants' belief in the value of the operation of entering numbers. However, this does not necessarily mean that the object of this belief is false.

Generally speaking, the type of framing of the Lost narrative favors a crisis of the principle of reality and of the relationship to knowledge. In fact, the series expands the internal focus on specific events meant to be reintegrated into a global framework, or even calls up contrary points of view on the same set of events, so that the value of the latter can change. This confrontation of dissonant points of view prompts us to represent coexistence as a crisis in the perception of reality for everyone. Moreover, if we refer to Todorov's analyses, the series rather follows the compositional codes of the fantasy genre mixed with science fiction. His writing imitates the documentary tone, of the archive or the recovered newspaper - an archaeological approach in which one explores the ruins of stations and watches old Dharma orientation videos, in order to present a factual or even objectively realistic dimension, while adopting the perspective of a character in fiction, relativizing objectivity and allowing the viewer's hesitation to persist. The audience does not know if they should ascribe a supernatural cause to the events depicted, a psychological cause, imaginary or real but still unexplained, given the technical and theoretical means at our disposal at present, until the moment of denouement, but then again...

Such ambiguity is particularly evident in a fantasy classic to which this season keeps referring, Henry James' The Turn of the Screw (1898). The work also conceals within itself the Swan station orientation video. In this short story, the author plays on the uncertainty as to the nature of the events told through a multiplicity of voices, conveying the narrative and creating a temporal distance between the two delegated narrative instances, as well as a reflection (by one of these voices) on a psychosexual determinism presiding over the enunciation of the latter. Thus, the delegated narrator tells the story of ghosts that another, a housekeeper, told her several years ago. But at the same time, she raises the hypothesis of a hallucinatory hysteria from which this "old maid" allegedly suffers. Hence the sexual double entendre of the title Turn of the screw. This play on words suggests that the short story could be understood as an exercise in formal writing, a configuration of utterly hollow effects and indifferent to its stated purpose, aimed at challenging readers tempted to identify what is or isn't real. In its second season, the series pushes this realistic logic of temporal distance and the deterministic explanation of the characters' experiences to a critical point that threatens the very reality of the narrative. Indeed, the deterministic explanation itself becomes a possible manipulation. Narration dissolves the receiver's primary belief with one hand while requesting it with the other. Fantastic ambiguity then becomes the ambivalence of a paranoid realism: one no longer has doubts about the nature of an event for one character, but about reality itself for several characters who themselves are at odds with each other and themselves. 
36 The recourse to the principles of cybernetics as applied to sociology and psychology evokes, by its very pretence of clinical objectivity, an enterprise of dehumanization with a concentrationist overtone. The use of the outdated media format of the tutorial video offers a viewpoint so abstract that it takes us from the fantastic into a universe where the objective reality opposing the particular subjective belief is nothing more than a social construction with a normative aim, an ideology. But this throwing into crisis of the real is the correlate of the breakdown of the characters' identities, which we discover increasingly divided without deigning admit it; flashbacks and other temporal configurations show us that they are doing more of the same. Here again, the world and the delegated narrators are like the manic-depressive narrator of Notes from Underground, for whom the empire of techno-science and the utilitarian morality of the modern world are the springs of an oppression that he hates because it undermines his eminent singularity, a singularity that nevertheless collapses in his impotent acrimony. The incorporation of codes of representation drawn from the experiments of behaviorist ethology - such as Skinner's boxes for conditioning rats - and from Stanley Milgram's psycho-sociological experiment on submission to authority and the spiral of engagement - to which the Pearl Station clearly refers - render our belief in the world narrated through the characters (and, by reflection, our belief in the real world) the result of a reifying, malevolent, totalitarian conditioning.

Such configurations revealing normative oppression underlying the real presupposes a narrative that focuses on characters who are increasingly struggling against themselves. Most of the flashbacks and other temporal variations of the narrative (with the possible exception of those of Jin and Sun and Bernard and Rose) depict traumatic events, when the impossible becomes possible, to use Kierkegaard's own language. However, the promises of happy events are often a prelude to a downfall caused by the character himself, who is inclined to repeat their failure on the Island. Moreover, through the resemblance between the flashbacks of the first season and those of the second, the narrative shows us protagonists who caricature themselves and sink deeper into a one-dimensional persona (Michael and Sawyer no doubt top the rest) becoming, of their own volition, the lab rats they purport not to be. Their behavior is obsessive and places them in double binds: they seek to relive the past as the past, thus running a kind of race to the bottom. For their action to "succeed", they place themselves in a context analogous to that in which their past action failed them. In the terms of Bateson's ecology of the mind, they find lose-lose situations by putting themselves in the position of fulfilling an injunction that presupposes a confusion of logical types and can only be achieved by departing therefrom. This context of schizogenic psychological violence through paradoxical communication is, moreover, a tenet of Joseph Heller's writing in "Catch-22", a novel that Desmond stumbles upon as he rescues Naomi (Marsha Thomason) in the aptly titled episode "Catch-22" (S03E17).

The double bind is part of a state of communication in which the confusion of logical types of a message and contexts of enunciation is inevitable and harmful to the interlocutor, leading to his systematic self-punishment. It requires two or more people; a repeating experiment; a primary negative injunction; an injunction contradicting it more abstractly, but just as negatively; a tertiary injunction forbidding the interlocutor to leave the situation. Bateson notes that schizophrenics and artists have a common tendency to confuse logical types (which is what poetic figures do) but that this confusion is positive, beautiful and moral, because it is flexible, in the artist. As we have 
seen with Desmond's play on words, "Lift her up", one of the challenges of Lost is to reveal the violence of these contradictions in order to defuse them and smooth over these supposedly lose-lose situations through comedy and through the narrative and its metaphorical virtualities, revealing this violent undercurrent and eliciting new types of responses.

In this sense, the series proposes a postmodern re-reading of the murky principle of reality of the modern rational universe in Baroque art: in episode "316" (S05E06), Ben, the manipulator, extols the leap of faith. He comments on the passage in chapter 20 of John's Gospel: "Because you saw me, you believed; taking paradoxically the example of a painting, The Unbelief of St. Thomas (1604) by Caravaggio, to reveal that one doesn't have to see to believe $e^{4}$. In doing so, the series highlights the artistic and sometimes highly ironic iconographic approach of the Italian master, whose work Poussin said was an effort to destroy painting. Nevertheless, it is above all the European theatrical works of the late 16th and early 17th centuries to which Lost refers. The series revisits the theme of Calderón's theatrum mundi, Shakespeare's tragic theater and romances, and Cornelius' fantasy comedies. The theater thus depicted the world as being in a box between symbolism and illusion, as a set of mnemonic images, numbers (or stations) giving us access to an occult culture, but also as a mechanical game of appearances with no objective background, a set of evanescent and vain phenomena existing only for the spectator's gaze. Thus, the recurring theme of these works is a questioning of the very existence of a plot or even of an author behind it, i.e. an authoritative individual: a king, a magician whom we tend to confuse with a Machiavellian usurper and an illusionist, a deus absconditus like Prospero on his island in The Tempest, whom we tend to confuse with an Evil Genius, his brother Antonio. This theme is so effectively dealt with that historical and literary critics regularly flourish with speculation that Molière or Shakespeare were merely usurpers or even the aliases of authors known to a happy few people.

The reference to the theater and to the authoritative role of the English poet is, however, patent: on the one hand, The Swan is the theater in which Shakespeare premiered his first dramas before the Globe - a geometrical volume whose shape could evoke the shape of a pearl and a gazing eye - and on the other hand, the circular shape of the Pearl station's logo refers to that of the Elizabethan stage. The stations thus function in concert: one is a synecdoche of the series, and the other places into a mise en abyme the role of the spectator, inevitably torn between disbelief in the face of deception, betrayal, and a willingness to believe in the story and in an author despite it all. This tug-of-war reaches its peak at the end of Season 2, in the episode "Live together, Die alone", where the question is whether pressing the button is an illusion given everything is filmed (and therefore designed for viewing), an observation that objectivizes the acts, emotions and perceptions of the characters into a collection of data, reducing the behavior to a series of automatic acts with no ending.

41 By way of reflection, the universe of the series appears to consist of an aggregate of narratemas, disparate promises worth as many test balloons, randomly combined to arouse an almost obsessive activity from the viewer, deriving from a repetition of signals and having a synthetic unity only by the mere projection of our desire. As Pacôme Thiellement wrote in the station La Perle, the viewer's gaze is indeed scrutinized. $\mathrm{He}$ is called upon to strive towards clairvoyance, according to the terminology of Jean-Luc Marion in L'Aveugle à Siloé: that is to say, he is called upon to 
discover for himself his position as a seer assuming a unilateral relationship between the Self and the Other. Otherwise he will constantly oscillate between the Pearl and the Swan in his relationship to the authors. Either the viewer believes that their gaze alone sets the TV show in motion, just as the oyster creates a pearl from scattered grains of sand, resulting in a narrative that they themselves could have written and elucidated better than its creators. Or they believe that the show exists entirely without them, created by a divine author similar to the serene swan that glides by and reflects the light, to use Proust's words in Jean Santeuil, that is to say an author who knows more about the story than he does and who of course knows more about himself, the viewer. In both cases, it is the same refusal to consider that the work takes its value in the relationship between the author and the viewer, in the proximity of the Other, by persuading oneself rather that the creation of the narrative comes from one of these two instances to the exclusion of the other.

Therefore, the temptation to mistakenly equate The Pearl with the totalitarian eye, the one that Anna Lucia discovered in the Arrow Station in "The Other 48 days" (S02E07) and which we learn in Season 3 belongs to Mikhail Bakunin (Andrew Divoff), the Russian revolutionary's namesake. This eye of Moscow sees society as Chernyshevsky's "crystal palace", which so excited the paranoia of the narrator of Dostoyevsky's Notes from Underground. Pacôme Thiellement thus reproaches the detractors of Lost, and especially the zealous inquisitors who became apostates in the last episode of Season 6, for this asymmetry in their view of the series: they wanted to read the narrative without letting themselves be read by it. To be read here means to revisit and develop the symbols beyond the illusions of omnipotence that they could provide when one tries to find an absolute and exclusive meaning hidden but encoded because it is accessible only to insiders, to the happy few involved in the Initiative. So it is necessary to give up single-handed control - the "let go" with which all the characters, starting with his father, serenade Jack during the series - in order to nourish a benevolent trust in Others.

43 By presenting the double bind interplay between the Pearl and the Swan, between a disenchanted and oppressive objective gaze and a fervent gaze, between Antonio and Prospero, John and Jack, the series also strives for something more. Cuse and Lindelof have not forgotten that in The Tempest, between Prospero and Antonio, there is Miranda ("Admirer" in Italian) who reconciles feuding brothers by falling in love with Ferdinand. Thus, between Locke and Jack, there is Desmond and Penelope (Penny) (Sonya Walger). It is thus a matter of regaining this naive trust in the world, giving up on control, revenge or retribution: Desmond's attitude, in the last two episodes of the season, points the way.

\title{
Live together, Die alone
}

\author{
"Dying for," "dying for the other." I also \\ considered calling my remarks "dying together ${ }^{5}$."
}

At the beginning of the first episode of Season 2's two-part finale, we learn the full name of the mysterious Desmond as Desmond David Hume, a homonym of the 18thcentury Scottish empiricist philosopher who referred to himself as a moderate sceptic. For Hume, our knowledge of facts rests on relations of ideas such as causality and identity, the existence of which cannot be demonstrated without a petition of 
principles. At the end of his first work, A Treatise of Human Nature, he analyzes the notion of identity, both subjective and objective, of the self or reality outside of the self, as a substance beneath the flow of thoughts and appearances, and concludes that it is not reduced to any impression. Identity, like causality, is a matter of imaginary belief and not of rational knowledge. The psychological habit of associating heterogeneous ideas leads us to suppose the permanent existence of the real and of oneself as the same as oneself, the self. Desmond, like Hume, doubts Locke's empiricism, which led him to doubt the hatch's validity through an experimental approach: What happens if you don't press the button? Which comes down to a straightforward logical proposition: pressing the button won't test whether or said act is saving the world, but not pressing the button will. This is an application of the modus tollens: if you press the button without the effect of world destruction, then pressing the button is not the cause of world salvation. But, for Hume, as for the same-named philosopher, the relation of implication being undemonstrable, this experiment will not be conclusive: the fact that nothing happens if one does not press the button does not necessarily prove that pressing the button was not the cause of the world's salvation. His examination of the Lockean evidence (the Pearl station film and hard-copy records) leads him to infer an alternative hypothesis: that Pearl's psychological experiment was not about the observed but the observers. Just as there is no identity attached to the observed object, there is none assigned to the observing subject. The subjectivity of the gaze is rather relative since the observers are themselves observable and, conversely, those who are observed are likely to themselves be observers. This is what we referred to earlier when we mentioned the fact that we are no longer voyeurs but voyants, as the series enjoins us to confess the relative and finite, even relational and intersubjective nature of our gaze.

It is therefore not the study of facts but of the moral and practical value of events and conjunctures of events that will serve as a basis for the beliefs of both David Hume and Desmond. At the end of the first part of A Treatise of Human Nature, the Scottish philosopher is bound by conflicting demands: in order to reorient his way of thinking and distinguish between truth, illusion and error, he must recognize the epistemological impossibility of this undertaking, and vice versa. It is the melancholy tempest of doubt; he wonders if he really knows about anything, and if such questioning even matters, since in the end there are only beliefs. Hence his stop: he decides to stop speculating from time to time to return to "ordinary life" and it is in the sentimental and moral life, dealing with responsibility, freedom, good and evil and others, that he will find the need to believe, even in speculation. It is the distinction between "to be " and "ought to be " that opens the last book of A Treatise of Human Nature that is used here, but radicalized, stripped of the utilitarian consequences that the Scottish thinker drew from it, and incorporated into a perspective of a metaphysics of the Other. The distinction is not utilitarian, for the series shows us that the duty to push the button seems proper insofar as it is a constraint, even a sacrifice that could hardly be dismissed as a self-interested calculation. Despite this, a deontological solution à la Kant whereby one must push the button without taking into account the particular consequences of the action, because it is the only form of rational freedom, is unconvincing - if one excludes the question of the primacy of the end. Clearly, Desmond's flashbacks, and Season 2 as a whole, show us that pushing the button for the sake of it, that is, resigning oneself to a hollow ritual, is alienating and alters one's personality. The buddy theme captures the ill-effects of this attitude: giving Desmond's comrade the name "Inman" (Clancy Brown) proves just as much. The name "Inman", 
literally "the inner man", hints at an extremely ambivalent relationship to the Other and to oneself, between schizophrenic hatred (a name invoking inner duality, the voices heard by the mentally ill - Desmond has the peculiarity of living out his flashbacks) and holiness (if we consider that the expression "inner man" in the Epistle of Paul to the Romans designates the man in his relationship of resemblance or "image of God" as opposed to the "outer man", Desmond being also the one for whom the Other is above all a "Brother").

So Desmond stopped doubting the merits of the Swan's undertaking somewhere along the way. We're meant to deal with the the ethically tenuous situation that is the leap of faith introduced by Jack's promise to Sarah. Certainly, it is because of the moral significance of the surgery and the events he experienced that Desmond reaffirms his attachment to pushing the button, but he only comes to realize it when he helps Locke not to push the button. It is by exposing himself to scandal, by allowing himself to doubt, that he discovers the singularly altruistic purpose behind an otherwise abstruse chore.

On the one hand, by seeing the error system lines of September 22, 2004, he takes the measure of his responsibility in the aviation disaster of Oceanic flight 815 , and not only because he was not present to input the numbers on time but because he should not have been absent. The consequence of this flight, and of the pursuit of his particular interest to the detriment of the general interest, is that he killed his hatch buddy. $\mathrm{He}$ then understands Locke's rage since he himself has borne Cain's sin, which is also that of Jacob in the episode "Across the Sea" (S06E15), this sacrifice of another for oneself, by killing Inman. This act of violence was the cause of the crash, and hence the genesis of the story.

However, Desmond remembers his first "meeting" with Locke who was knocking on the hatch, distraught over Boone's death, just as he sought to commit suicide after finding, between the pages of Dickens' A Mutual Friend, Penelope's letter proclaiming her faithfulness. Locke blames the Island for Boone's death because his identity consists of a relationship, that is, a relationship to another who doesn't recognize himself as such, who thinks he is alone versus everyone else. Locke never stops defining himself according to a destiny promising omnipotence that can only end cruelly. His leitmotiv, "Don't tell me what I can't do", is the very aphorism of the asymmetry mentioned above: he demands the presence of the other in order to dismiss her, while at the same time striving for his own impotence to restore a necessarily belittling presence. Locke thus defines himself against and based on the distorted image he has of the Other, of the Island, of his father. Hume, on the other hand, blames himself for Inman's death and discovers the suicidal logic underpinning the pursuit of honor that he has always espoused, the logic of a morbid relationship with the Other, the false image he has of his fiancée's father Charles Widmore (Alan Dale), the chief Other. He grasps this when he reads Penelope's letter and realizes that he has shut himself out of the relationship he had with her and that his race was an escape, which Charles had already told him and which he failed to understand: "You just run away". But, paradoxically, this awareness of his wrongdoing has already begun to save him, even if he does not yet hear the words of his fiancée. The conjunction of the solitudes of Locke and Hume, of his two feeble prides, is, at the outset, experienced as happy because it serves the interest and self-esteem of both characters. This conjunction could be the fruit of chance or fate. Nevertheless, when it is remembered, repeated in a context of extreme 
crisis, the coincidence of these trajectories associated with the memory of Inman's murder becomes significant according to Penelope's words promising that she is waiting for Desmond, that she gives herself to him and that he must remember that he is loved. To these words, which will be recalled off-screen, he buys into a mutual relationship with the Other and understands everything that has happened to him as the repayment of a gift: "But you saved my life, brother, so that I could save yours," he then says to Locke before sacrificing himself, simultaneously attributing this underlying meaning to the series' plot.

This final sequence, like Jack's death in the episode "The End" (S06E17), can be construed as a rereading of the sacrifice of Spock (Leonard Nimoy) the half-Vulcan, half-human in Star Trek II: The Wrath of Kahn (directed by Nicholas Meyer, 1982). Spock designed the Kobayashi Maru test, a simulation of a lose-lose situation in which the cadet must "learn" to lose, accepting the necessity of objective reality. Kirk (William Shatner), the man of action (even of faith, since this name is reminiscent of Kierkegaard, "Kierke" meaning "church"), is the only one to have passed this test by cheating, arguing that learning to lose is not learning. He regards Spock's realism and logical detachment as morbid resignation. Spock's sacrifice is a resolution of this dilemma. By entering the heart of the nuclear reactor of the starship Enterprise to save the crew, he resigned himself to the only logical choice: the life of an individual counts less than that of the Whole. However, at the same time, being half human, his choice is more than rational; it has a singular affective dimension at the order of belief, trust in his friendship with Kirk. This comparison strikes us as justified because, in addition to the audiovisual and dramatic nods to the film and its remake in 2014 by Abrams and Lindelof, Kirk's recitation of Spock's eulogy, which prefigures his resurrection in Star Trek III: The Search for Spock (directed by Lindelof and Abrams), is also justified. Leonard Nimoy, 1984) ends Dickens' A Tale of Two Cities ("It is a far, far better thing that I do, than I have ever done; it is a far, far better rest that I go to than I have ever known.") which provides the title of the first episode of Lost's third season.

We shall conclude by noting that the whole problem of belief in the world of narrative and in its common order necessarily takes on, in this Season 2, a despairing aspect in order to bring about the leap of faith and the possibility of its reiteration. The promise can only be heard through a paranoid accrual of doubt equivalent to the "teleological suspension of ethics". Kierkegaard's expression designates the phase of despair produced by resigning oneself to duty, which seems absurd to us if repeated only as a matter of form. Nevertheless, it is out of this desperate consciousness leading us to a situation of potential transgression of the said duty, that paradoxically proceeds, by an effect of dialectical reversal, the revelation of the well-foundedness and transcendent destination of this same duty. Hence the ambivalence of the reiterating entry of the numbers: it has both an abstract and alienating aspect, but it is also liberating. As a ritual, it systematically and symbolically repeats the incident whose nature is revealed at the end of Season 5. The incident is a sacrifice of others for oneself, or even of oneself against others, as Jack launches the H-bomb onto the site so that the crash doesn't happen and the story doesn't take place either, depriving everyone of the spectacle of the demise of the hero he thought he was. Pushing the button allows us to commemorate this original traumatic experience of crossing the line, when the impossible becomes possible, to keep evil at bay, as does the sarcophagus containing the source of the turbulence. 
51 We can however distinguish between repetition as reproduction and re-creation. As reproduction, the operation is alienating because the repetition of the ritual is also a form of oblivion since it tends to repeat itself, substituting for a mythology for the initial incident, that is, a retrospective and ideological teleology - such as that governing most flashbacks of characters who represent their trauma with a relative egocentric complacency fuelled by a lack of self-knowledge. This is why the operation produces a form of dogmatic resignation leading to doubt and despair, which attacks this superficial mythology, then leading to ritual through a sacrifice of hatred of the other for oneself, or of oneself against the other, as is John's challenge to stop pushing the button, or Jack's challenge to detonate the H-bomb in the episode "The Incident" (S05E16-17). Repetition reveals that these characters drive towards the end, the end of the other, their own end, that of the story; they seek the apocalypse in the conventional sense, that of catastrophe, of violence transcending all reason. And yet, at the height of the crisis, the operation acquires an original meaning, that of the promise behind the incident, behind the sarcophagus. The doubt produced by the repetition of the operation becomes a revelation for Desmond, through Penelope's patience. This revelation, the literal meaning of the term "apocalypse", is that the only answer to this situation is self-sacrifice for the other who is transcendence, the beyond of the narrative on which it is based. This sacrifice is represented by the opening of the coffin that is the Swan. The coffin is the promise of Lost, Christian's coffin which remains open and empty near the source and the remains of "Adam and Eve" in the episode "White Rabbit" (S01E05) and around which Christian makes peace with his son and reunites the survivors at the end of the series. That's why Desmond has the key, perhaps even is the key to the series and why his flashback scheme is unique: he doesn't represent himself but lives his past, being actually present to himself. Repetition therefore paves the way to a re-creation and becomes properly religio - in the sense of the impugned etymology of Lactantius, this time, that is to say religio that which joins men together and binds the immanent to the transcendent. Iy brings about a world shared by all walks of life, a simultaneous unity of a universe of coexistence of conscious subjects by opening the coffin.

Explaining Jack's experience from the episode "Man of science, Man of faith", the lesson Desmond Hume gives us, at the end of the season, is that this transcendental instance is another and that it is close to us in its infinite distance. The important thing is therefore not so much in what, but in whom, one wishes to believe, that is to say in the other in his difference, patience, and distant proximity, as the end of the episode "Live together, Die alone" attests. By sacrificing himself to blow up the Swan station, Desmond causes another dimension to exist - the first and only reverse camera, or even off-screen view, on the Island, which is neither memory, nor flashforward, nor flashsideways, but contemporary to the survivors' adventures, and a sign of a joint presence, the one in whom to trust and believe, Penelope. 


\section{BIBLIOGRAPHY}

BATESON Gregory, Vers une Ecologie de l'Esprit 2, Paris, Seuil, 2008.

BENVENISTE Emile, Le Vocabulaire des institutions Indo-Européennes : Pouvoir, Droit, Religion, Paris, Éditions de Minuit, 1969.

BORTZMEYER Gabriel, « Serial Cruiser », Trafic n90, Paris, POL, 2014, p.45-58.

CICERON, La Nature des dieux, Paris, Les Belles Lettres, 2002.

COLERIDGE Samuel, La Ballade du vieux marin et autres textes, Paris, Gallimard, 2007.

DICKENS Charles, Un Conte de deux villes, Paris, Folio, 1989.

DOSTOÏEVSKI Fiodor, Les Carnets du sous-sol, Arles, Actes Sud, 1992.

_-_. Les Frères Karamazov, Paris, Folio, 1994.

ECO Umberto, De Superman au Surhomme, Paris, Le Livre de Poche, 1995.

GIRARD René, Mensonge romantique et Vérité romanesque, Paris, Pluriel, 2010.

HATCHUEL Sarah, Lost : Fiction vitale, Paris, Presses universitaires de France, 2013.

HUME David, Système sceptique et autres systèmes, Paris, Seuil, 2002.

IRWIN William et Kaye SHARON, Lost and Philosophy: Think together, Die alone, Hoboken, John Wiley and Sons, 2010.

KIERKEGAARD Søren, La Reprise, Paris, Garnier-Flammarion, 1990.

_--. Crainte et Tremblement, Paris, Payot-Rivages, 1999.

_-_. Le Traité du désespoir, Paris, Folio, 1988.

LACTANCE, Institutions divines (Livre IV), Paris, Cerf, 1992.

LÉVINAS Emmanuel, Entre nous, Paris, Le Livre de Poche, 1990.

MARION Jean-Luc, La Croisée du visible, Paris, Presses Universitaires de France, 2007.

PASCAL Blaise, Pensées, Paris, Folio, 2004.

THIELLEMENT Pacôme, Les mêmes yeux que Lost, Paris, Léo Scheer, 2011.

TODOROV Tzvetan, Introduction à la littérature fantastique, Paris, Seuil, 1976.

WEINRICH Harald, Le Temps, Paris, Seuil, 1973.

\section{NOTES}

1. David Hume, Système sceptique et autres systèmes, Paris, Seuil, 2002, p. 251.

2. See Dostoevsky, p. 61.

3. Voir Dostoevsky, Les Carnets du Sous-Sol, Paris, Actes Sud, 1992, p. 37.

4. The reference to this episode is further confirmed by the fact that, according to Pacôme Thiellement, the Pearl alludes to the parable of the pearl in the Gospel of Thomas - a story that serves as the plot for the film Knight of Cups (Terence Malick, 2015).

5. Emmanuel Lévinas, Entre nous, Paris, Le Livre de Poche, p. 212. 


\section{ABSTRACTS}

This essay deals with the themes of the leap of faith, the ritual and the sacrifice in the television show Lost, concentrating mainly on season 2. It questions Lost's promise to spectator as far as narration is concerned. This promise seems to be paradoxical: the story requires the viewer to be suspicious and even to distrust what $s /$ he sees. Our work examines the Swan Station apparatus and the opposition between belief and knowledge which is reflected in the antagonism between Jack Sheppard and John Locke and finds a solution in the sacrifice of Desmond Hume. The essay analyses the episodes "Man of science, Man of faith" (S02E01), "?" (S02E21) and "Live together, Die alone" (S02E23-24). The first episode is interpreted in relation to Kierkegaard's works to show that belief and knowledge are two phases before a character's leap of faith, which consists in being open to others. However, the repetition of this leap is problematic; the second episode is understood as a focalisation on the despair of one character, Locke, who gives us a reflexion on the way to look at the TV show as an undecidable oscillation between distrust and trust, i.e. between the Pearl and the Swan. The third one, compared with David Hume's writings and to Star Trek II: The Wrath of Kahn, allows to reveal the solution offered by the show, which would be selfsacrifice, mainly the sacrifice of one's own pride, evident in Desmond and Penelope's relationship.

Notre article étudie les thèmes du saut de la foi, du rituel et du sacrifice dans la série Lost en interrogeant surtout la saison 2. Par voie de réflexion, il interroge la promesse de Lost, c'est-àdire le type de crédit que le récit prescrit au spectateur d'accorder à ce qui est raconté. La promesse paraît paradoxale, le récit exigeant de se méfier voire de se défier pour mieux croire. Notre travail examine à cet effet le dispositif de la Station du Cygne et l'opposition entre croyance et savoir paraissant se cristalliser dans l'antagonisme de Jack Shephard et John Locke et se résolvant dans le sacrifice d'une figure intermédiaire, Desmond Hume. Il analyse donc les épisodes « Man of science, Man of faith» (S02E01), «? (S02E21) et «Live together, Die alone » (S02E23-24). Le premier épisode est interprété à l'aune de l'œuvre de Kierkegaard pour montrer que croyance et savoir sont deux phases pour un même personnage vers le saut de la foi qui consiste dans l'ouverture à autrui. Cependant la répétition de ce saut est problématique. Ainsi le deuxième est compris comme une focalisation sur le désespoir d'un personnage, Locke, offrant une réflexion sur la manière de voir la série comme une oscillation indécidable entre méfiance et confiance, la Perle et le Cygne. Le troisième, comparé aux écrits de David Hume et au film Star Trek II: The Wrath of Khan, permet d'exposer la solution que propose la série, qui serait le sacrifice de soi (et surtout de son orgueil) pour l'autre, manifeste dans la relation de Desmond à Penelope.

\section{INDEX}

Mots-clés: Lost, suspension volontaire d'incrédulité, scepticisme, foi (acte de), sacrifice, répétition, baroque, Hume David, Kierkegaard Søren, Dostoïevski Fiodor

Keywords: Lost, suspension of disbelief, skepticism, leap of faith, sacrifice, repetition, baroque, Hume David, Kierkegaard Søren, Dostoïevski Fiodor 


\section{AUTHORS}

\section{GUILLAUME DULONG}

Guillaume Dulong, who holds an 'agrégation' in philosophy and a PhD in film studies, is a professor of philosophy and cinema in high school; he also teaches cinema at the University of Bordeaux Michel de Montaigne. Inspired by the theories of André Gaudreault and of Tom Gunning, his PhD thesis explored the filmic genre of fantasy and the influence of digital technologies on contemporary narration.

Guillaume Dulong, agrégé de philosophie et docteur en études cinématographiques, est professeur de philosophie et de cinéma en lycée, ainsi que chargé de cours en cinéma à l'université Michel de Montaigne Bordeaux III. S'inspirant des théories d'André Gaudreault et Tom Gunning, son travail de thèse a porté sur le genre cinématographique de l'imaginaire et l'influence des technologies numériques sur les modes de narration contemporain de fantasy. 